\title{
A Financial Optimization Model as a Business Model for Measuring and Managing the Value of Companies: In the Context of Good Corporate Governance (GCG)
}

\author{
Siti Nuryanah ${ }^{1 *}$ \\ ${ }^{1}$ Faculty of Economics and Business, Universitas Indonesia, Depok 16424, Indonesia \\ *Corresponding Author: siti.nuryanah@ui.ac.id
}

\begin{abstract}
The purpose of this paper is to develop an integrated financial model using an optimization approach as a business model for measuring and managing the value of companies to achieve Good Corporate Governance (GCG). The model uses the discounted cash flow valuation model and is based on accurate and reliable accounting information so that it provides sound financial management strategies to manage the value of the company. The integrated financial model offers a significant contribution to the literature because it provides a managerial application model showing interactivity between individual governance variables, as well as considering external governance mechanisms. This would be of significant benefit to organizations in pursuing GCG practice and managing their companies' values. From an academic point of view, this research fills the vacuum of a business model using an integrated financial application model which encompasses both corporate governance practices and external regulatory environments.
\end{abstract}

Keywords: Business Model; Financial Modelling; Optimization Model; Corporate Governance.

\section{INTRODUCTION}

The outrageous corporate collapses following the phenomena of corporate failure around the world in recent decades have raised the need for urgent GCG practice ${ }^{1}$. The volatile global economy and the dynamic business environment have been viewed as risks for companies, since they influence companies' success in creating value ${ }^{2}$. Theoretically, the implementation of GCG would benefit the company, since it manages and minimizes risks, thereby increasing the value of the company and making it sustainable $e^{3-5}$. There is compelling evidence in the literature for the favorable impact of GCG on company performance ${ }^{5-8}$. The GCG practice ensures the achievement of economic benefits by making the use of company resources efficient, thereby underpinning growth and increasing company performance ${ }^{3,8}$.

Financial crises and corporate collapses have raised questions about GCG practice, since some companies which claimed to have implemented corporate governance have, in fact, collapsed, while many other companies still cannot achieve value maximization and derive benefit from its implementation ${ }^{1,9}$. History has been repeated and responses have been made but the failures continue. Many companies realize the essential need for GCG and sound financial management strategies, so why is there still company failure and why is it that a company which claims to have implemented corporate governance still cannot achieve value maximization? Indeed, in this turbulent economy, when the company's objective is to maximize its corporate value, the main problem is how to manage and minimize risks. Specifically, from corporate governance (CG) perspective, the question is what does 'good' mean in both good corporate governance and good financial management?

Despite the fact that implementing a real sound CG system is the answer, quantification of the normative CG concepts into a business model is considered relevant for achieving successful GCG, as the business model provides a more structured tool to enable management to achieve the strategy ${ }^{10}$. A business model based on an integrated corporate financial model is important. The integrated financial model needs to reflect all business environments and risks faced by a company so that management can undertake risk management activities and thus minimize costs while maintaining the company's value creation activities. The business model proposed by this study is an integrated financial model using an optimization approach for measuring and managing the value of companies to achieve GCG. To the authors' knowledge, this has not been done before. How a company can utilize internal governance mechanisms to minimize risks, thereby maximizing the company's value, is further discussed in this paper. Moreover, this study fills the research gap with regard to business models, as previous models are identified as lacking theoretical justifications of economics and business studies ${ }^{10}$. Providing a clear management strategy, 
internal company resources and risks as a proxy for external factors faced by the company, and having the functions of control and financial planning, the proposed integrated financial model can be identified as a business model ${ }^{10}$.

In addition to the literature on optimization models, literature shows that optimization has been widely utilized for financial decision-making ${ }^{11-19}$. However, the existing financial models have overlooked some important points of business models which mean that they are not reliable for decision-making: i.e. 1) the current financial models do not reflect the real environments faced by companies, such as the dynamics of the economic condition, business and regulatory environments, and the uncertainty of the future; 2) the existing models neither consider current practice of GCG nor identify risks which influence the value of a company; 3) the existing financial models contain accounting noise.

The present paper demonstrates the application of an optimization model as a business model in corporate governance and finance to measure and manage the value of a company in achieving GCG practice.

\section{LITERATURE REVIEW}

The structure of the conceptual framework to improve a company's GCG practice is presented in Figure 1. Theories of corporate governance and the literature mentioned previously suggest benefits from the correct implementation of corporate governance: i.e., it increases the value of the company, since the market reacts positively to the GCG practice.

Internally, GCG practice needs to be derived into internal governance instruments. Then, since GCG concepts ${ }^{20}$ suggest that a company needs to take into account regulatory environments, i.e. external governance instruments developed by stock market authorization (i.e. capital and financial market characteristics), regulators (i.e. tax and fiscal policy), and professional and business practice (i.e. accounting practices), the internal governance mechanisms which are developed by management also need to accommodate the external mechanisms. In general, these internal governance instruments can be applied in three main activities of the company: operating, investing and financing. This GCG practice is finally conveyed to the external stakeholders through, for example, accounting numbers. The market as the representative of external stakeholders will then respond to this GCG practice by adjusting the market value of the company's stock price ${ }^{20}$. Therefore, it is important for a company to ensure that the market will respond positively to its corporate governance practice.

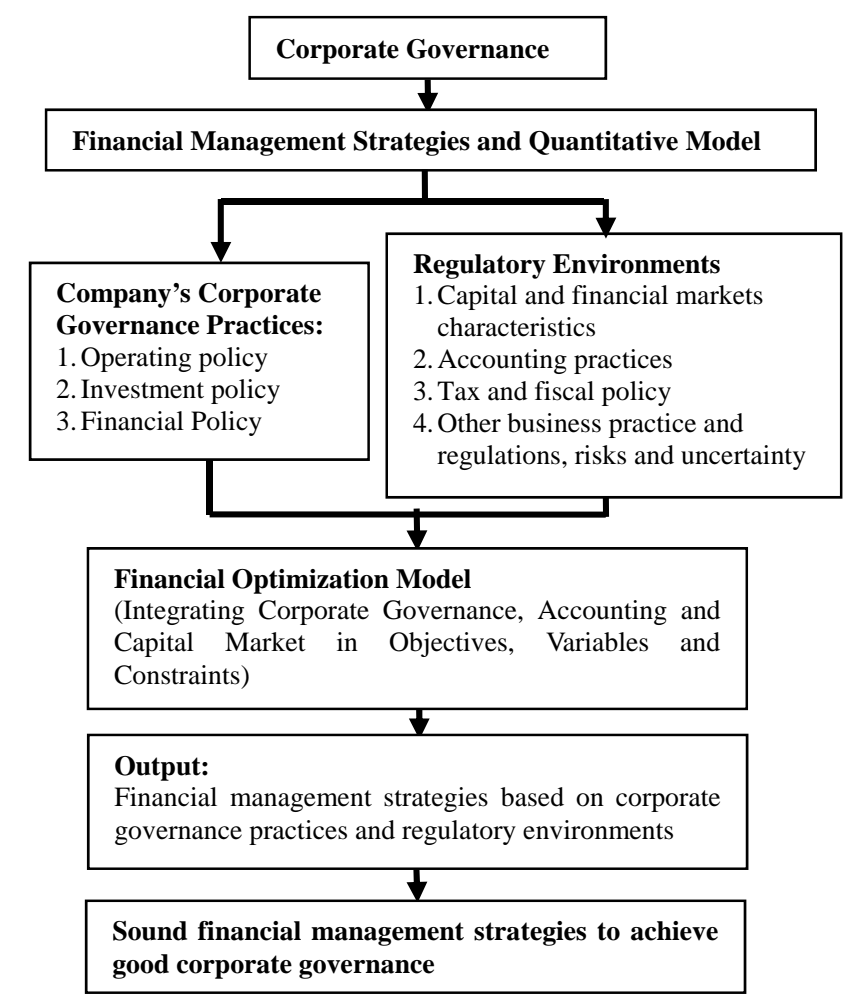

Figure.1. Conceptual Framework of an Integrated Financial Model using Optimization Approach for Sound Financial Management Strategies

This can be done by assessing and measuring the monetary effects of the company's corporate governance practice using a business model called a financial optimization model. The output of this model would be sound 
financial management strategies which ensure the achievement of GCG and the improvement of the firm's value as a result of the GCG practice.

\section{RESEARCH METHOD}

A multi-objective optimization model will be used as a business model to measure and manage the value of a company for achieving GCG. The model is built by making use of quantitative data from the accounting, finance and capital market. As a business model, this project attempts to capture the dynamics of business environments by using a multi-year linear programming model. Five-year predictive data based on sales growth forecasting is needed as an input for the model. The model proposed by this paper extends the Carleton model ${ }^{12,13}$.

An income approach valuation based on the discounted cash flows (DCF) model is used. The DCF model as an income approach measurement is more suitable than other methods for calculating the intrinsic value of a company and assessing its financial health and profitability ${ }^{22}$. DCF is also used to minimize the effect of accounting noise. This paper applies the model to assess the corporate governance practice in three main activities of a company: operating, investing and financing activities.

\section{Objective Function}

To operationalize the OECD GCG principle 4 that relates to the interests of shareholders and stakeholders, the objective functions of this model are developed as follows:

1) GCG ensures the profitability and sustainability of the company's operating activities: Maximize cash flows from operating (proxy by cash flow from operating)

2) GCG ensures a positive return on investments: Maximize return on investments (proxy by economic profit)

3) GCG ensures the fulfillment of the return of debt holders and minimizes the financial distress and bankruptcy risks: Minimizes returns for debt-holders (proxy by debt-service coverage ratio)

4) GCG ensures the fulfillment of the return of shareholders: a) Maximize free cash flows to equity (FCFE) (proxy by FCFE); b) Maximize earnings per share (proxy by EPS)

\section{Constraints}

\section{Operating and Accounting Policy Constraints}

Accounting - Tax Difference (Accounting for Income Tax): Effects of Tax Regulation

Differences between accounting principles and tax codes create permanent and temporary tax differences. Management must consider the effect of permanent differences, since it cannot be recovered forever and it puts the company into tax risk by paying higher tax expenses. Therefore, the management needs to control the (positive) effect of permanent differences, which causes higher taxable income, by controlling the non-deductible expenses.

\section{Account Receivable (AR) Level}

The risk related to AR is uncollectible ARs, which then influence the company's liquidity. Therefore, a faster collecting time for the outstanding account receivables is better for the company. Since AR comes from credit sales activity, the management control related to the accompanying risk is achieved by making the AR turnover faster; the constraint is benchmarked to the historical and industry data.

\section{COGS and Inventory Amount}

Two types of risk related to inventory are excessive inventory (causing significant carrying costs) and low-level inventory (leading to stock outs, lost sales and unsatisfied customers) ${ }^{23}$. It is important for management to minimize these risks by, for example, estimating how quickly the company can sell its inventory. A common measurement which can be used by managers to manage these inventory risks is inventory turnover (or average days to sell inventory); the constraint is benchmarked to the historical and industry data.

\section{Corporate Governance Policy: Risk Management, Financial and Investments Policy Constraints Working Capital Policy}

This policy is related to the company's ability to minimize liquidity risks; it represents the ability of the company to pay its current liabilities (risks in short-term). This policy is also recognized as a short-term investment policy: investment in current assets. It is important, since it shows the company's ability to run its day-to-day operating activities. The ratio between current assets and current liabilities should be based on the assessment of historical data and the industry.

\section{Financial Distress and Bankruptcy Risk: Leverage Policy}

Financial distress, bankruptcy and their costs are highly related to the debt amount or leverage of the company ${ }^{24}$. To minimize the bankruptcy and solvency risks or to maintain the company's ability to fulfill its long-term debt 
(risks in the long term), the total debt-to-assets ratio must not be more than the total debt-to-assets ratio of the industry.

\section{Investment Policy}

Capital Expenditure

Every investment decision on capital expenditure must consider the capacity of the assets: i.e., the acquisition of a machine to meet growth in existing products needs to consider the productivity capacity of the machine, which relates to the unit quantity of sales. For this study, since specific data for analyzing each capital expenditure are not available from public information, the constraint for the capital expenditure is based on the industry: the contribution of fixed assets to the sales growth. For the activity ratio, the activity of the company's fixed assets must be equal to or more than those of the industry. Then, since capital expenditure is important for sustainability of the company, the growth rate of current capital expenditure should be at least equal to or greater than the rate in previous periods. Average data for the industry over more than one year is also needed, since fixed assets have long-term economic value.

Available Funds for Investments

The total resources which a company can use for long-term investments include internal funds and external financing activities: issuing stocks and issuing long-debt instruments. Based on pecking order theory, internal funds are preferable to external funds ${ }^{25-27}$.

\section{Compensation for Executives}

There are many types of management compensation, mostly related to accounting earnings and stock prices. Unfortunately, there is no empirical consensus on how these compensations affect the value of a company ${ }^{28,29}$. In fact, best incentives as part of governance instruments need to be constructed so that they minimize the agency costs by minimizing the moral hazard of the managers but still encourage managers to make their best efforts to maximize the shareholders' wealth, and therefore the best incentives for managers should be based on the GCG criteria.

\section{DISCUSSIONS AND CONCLUSION}

This paper has described a preliminary stage of the development of a business model using an integrated financial optimization model to measure and manage the value of companies in achieving GCG practice. To fulfill the criteria of a business model, the model proposed a very clear management strategy: i.e. to ensure that the value of a company is in line with the spirit of the implementation of GCG and GCG principles that protect shareholders' and stakeholders' interests. The model also proposed some features which are also relevant for a business model. This includes, for example, internal company resources and risks as a proxy for external factors faced by the company, which function as a control of the model. The last characteristic of the business model is financial planning, which was also proposed by this paper.

Simulation of the model will be the next step. Constructing and applying a business model based on an integrated financial optimization model from managerial and financial accounting perspectives, this study may show how GCG is achieved via sound financial management that reduces risks and improves company performance.

Finally, the proposed business model would be more useful if future research could extend in the area of, for example, projection or prediction of the future value of the company. The intrinsic value of the company, calculated based on the expected value of its future cash flows, can be compared with the company's fundamental value or current market price, and is therefore more useful in assessing whether a company's stock is under- or over-valued.

\section{REFERENCES}

[1] F Clarke, G Dean, K Oliver. Corporate Collapse: Accounting, Regulatory and Ethical Failure, $2^{\text {nd }}$ Edition. Cambridge University Press, Cambridge (2003).

[2] GS Dallas. Governance and Risk: An Analytical Handbook for Investors, Managers, Directors, and Stakeholders. McGraw-Hill, New York (2004).

[3] Organisation for Economic Co-operation and Development (OECD). OECD Principles of Corporate Governance. Organisation for Economic Co-operation and Development (OECD), Paris (2004).

[4] Organisation for Economic Co-operation and Development (OECD). Corporate Governance and Financial Crisis. Organisation for Economic Co-operation and Development (OECD), Paris (2009).

[5] P Gompers, J Ishii, A Metrick. Corporate governance and equity prices. The Quarterly Journal of Economics, 118(1) (2003) 107-155.

[6] S Beiner, W Drobetz, F Schmid, H Zimmermann. Is board size an independent corporate governance mechanism?. Kyklos, 57(3) (2004) 327-356.

[7] BS Black, H Jang, W Kim. Does corporate governance predict firms' market values? Evidence from Korea. Journal of Law, Economics, and Organization, 22(2) (2006) 366-413.

[8] L Brown, M Caylor. Corporate governance and firm operating performance. Review of Quantitative Finance \& Accounting, 32(2) (2009) $129-144$. 
[9] HIH Royal Commission. The Failure of HIH Insurance: A Corporate Collapse and Its Lessons. Commonwealth of Australia, Canberra (2003).

[10] BW Wirtz, A Pistoia, S Ullrich, V Göttel. Business models: Origin, development and future research perspectives. Long Range Planning, 49(1) (2016) 36-54.

[11] DR Anderson, DJ Sweeney, TA Williams. An Introduction to Management Science: Quantitative Approaches to Decision Making, $11^{\text {th }}$ Edition. South-Western, Nashville (2005).

[12] WT Carleton. Linear programming and capital budgeting models: A new interpretation. The Journal of Finance, 24(5) (1969) 825-833.

[13] WT Carleton. An analytical model for long-range financial planning. The Journal of Finance, 25(2) (1970) 291-315.

[14] SI Gass, CM Harris. Encyclopedia of Operations Research and Management Science, $2^{\text {nd }}$ Edition. Springer, New York (2001).

[15] WF Hamilton, MA Moses. An optimization model for corporate financial planning. Operations Research, 21(3) (1973) 677-692.

[16] Y Ijiri, FK Levy, RC Lyon. A linear programming model for budgeting and financial planning. Journal of Accounting Research, 1(2) (1963) 198-212.

[17] AC Lee, JC Lee, CF Lee. Financial Analysis, Planning and Forecasting: Theory and Application, $2^{\text {nd }}$ Edition. World Scientific, Singapore (2009).

[18] H Shahnazarian. A dynamic microeconometric simulation model for incorporated business. Sveriges Riksbank Occasional Paper Series, 11 (2004).

[19] JM Warren, JP Shelton. A simultaneous equation approach to financial planning. The Journal of Finance, 26(5) (1971) 1123-1142.

[20] T Clarke. Theories of Corporate Governance: The Philosophical Foundations of Corporate Governance. Routledge, London (2004).

[21] EF Fama. Efficient capital markets: A review of theory and empirical work. The Journal of Finance, 25(2) (1970) 383-417.

[22] T Koller, M Goedhart, D Wessels. Valuation: Measuring and Managing the Value of Companies, $5^{\text {th }}$ Edition. John Wiley \& Sons, New Jersey (2010).

[23] JJ Weygandt, K Chalmers, L Mitrione, M Fyfe, D Kieso, PD Kimmel. Principles of Accounting, $2^{\text {nd }}$ Australian Edition. John Wiley \& Sons Australia, Milton (2010).

[24] R Castanias. Bankruptcy risk and optimal capital structure. The Journal of Finance, 38(5) (1983) 1617-1635.

[25] SA Ross. Fundamentals of Corporate Finance, $7^{\text {th }}$ Edition. McGraw-Hill, Boston (2006).

[26] AJ Keown, JD Martin, JW Petty. Foundations of Finance: The Logic and Practice of Financial Management, $7^{\text {th }}$ Edition. Prentice Hall, Boston (2011).

[27] SC Myers. The capital structure puzzle. The Journal of Finance, 39(3) (1984) 575-592.

[28] JE Core, WR Guay, DF Larcker. Executive equity compensation and incentives: A survey. Economic Policy Review, 9(1) (2003) 27-50.

[29] DI Walker. Evolving executive equity compensation and the limits of optimal contracting. Vanderbilt Law Review, 64 (2011) 611-674. 